\title{
ANTIOXIDANT ACTIVITY AND TOTAL PHENOL AND FLAVONOIDS ANALYSIS OF SIBERIAN GINSENG ROOT
}

\author{
NAGENDAR SHETTY1, V. HARIKA ${ }^{2}$, SUMITRA LOKRAS ${ }^{3}$ \\ ${ }^{1}$ Renatus Wellness Pvt. Ltd. Hyderabad, 500051, India, 2,3St Francis College for Women, Hyderabad, India \\ Email: rohit@renatuswellness.net
}

Received: 17 Sep 2019, Revised and Accepted: 28 Nov 2019

\begin{abstract}
Objective: This study was examined to in vitro antioxidant activity and Total Phenol and Flavonoids content analysis of methanolic root extract of Eleutherococcus senticosus (Siberian ginseng).
\end{abstract}

Methods: 1,1-dephenyl-2-picryl-hydrazyl free radical scavenging and FRAP assay propose that antioxidant activity of methanol root extract because of reducing capacity of the antioxidant against oxidative effects of reactive oxygen species.

Results: Scavenging activity of Siberian ginseng root RC50 value was shown $713.42 \pm 11.55 \mu \mathrm{g} / \mathrm{ml}$ and reducing power $0.13 \pm 0.01 \mathrm{mmol} / \mathrm{g}$ was investigated. In addition, total phenol $12.6 \pm 1.13 \mathrm{mg} \mathrm{GAE} / \mathrm{g}$ DW and total flavonoids $9.8 \pm 0.20 \mathrm{mg}$ QE/g DW were recorded.

Conclusion: Although all tests were performed in vitro assay, these results recommend that Siberian ginseng root may be a good source of antioxidant ingrediant.

Keywords: Eleutherococcus senticosus, Scavenging activity, Phenol, Flavonoids, Siberian ginseng

(C) 2020 The Authors. Published by Innovare Academic Sciences Pvt Ltd. This is an open-access article under the CC BY license (http://creativecommons.org/licenses/by/4.0/) DOI: http://dx.doi.org/10.22159/ijcpr.2020v12i1.36830. Journal homepage: https://innovareacademics.in/journals/index.php/ijcpr

\section{INTRODUCTION}

Eleutherococcussenticosus also called Siberian ginseng, is a medicinal plant. Siberian ginseng, from the family Araliaceaecirculated in Northeast China, Southeast Russia, Japan and Korea [1]. The root of Siberian ginseng are extensively used as a traditional Chinese medicine used to strengthen the spleen and nourish the kidney. In the extract of Siberian ginseng, saponins, lignans, triterpenoid, coumarins, and flavones. Phenolic compounds such as eleutheroside $\mathrm{E}$ and syringin have been reported to have a variety of medicinal anti-leishmania, anti-gout, antihyperglycemic, anti-hepatitis, immunostimulatory, effects concerning antibacterial, anticancer, anti-inflammatory, haemostatic, hypocholesterolemic effects and antioxidant activity [2-4].

The pharmacological activity of natural products is very regularly believed to be the result of the combined of constituents. The major compounds of E. senticosus are polyphenols. These compounds comprise-eleuthero sides, flavonoids and phenolic acids. The roots of E. senticosusare good resource of phenols, called as eleutherosides and flavonoids, triterpenic acids, phenolic acids and anthocyaninsmainlyeleutherosides B, E, E1.

Currently, in China root ethanol extract of Siberian ginseng is a prevalent health supplement for impotence, weakness and diseases connected with inflammation. Several other properties of eleutherosides from E. senticosuscontainand increased glucose uptake in $\mathrm{C} 2 \mathrm{C} 12$ myotublesand alleviation of insulin resistance in $\mathrm{db} / \mathrm{db}$ (obese type 2 diabetic) mice [5], increased endurance capacity and cardiovascular function in athletic training over an 8-week, neuroprotectiveeffects during neural ischemia in rats [6], further growth inhibition and apoptosis in stomach cancer cells (KATO III cells) [7], anti-inflammatory effects [8] and interestingly also cancer [9], with glycoproteins from Acanthopanaxsenticosus (glycoproteins (EN-SP) showed anti-tumor effects [10].

This study to evaluate the primary analysis of bioactive compounds and Total Phenol and Flavonoid content anlaysis of siberian ginseng root. We also investigated antioxidant capacity. Siberian ginseng root showing good antioxidant capacity, it may be use for health supplemt in pharma industry.

\section{MATERIALS AND METHODS}

\section{Materials}

The Siberian ginseng root was procured from traditional plant suppliers. Butylated hydroxytoluene (BHT), 1,1-diphenyl-2picrylhydrazyl (DPPH), Folin-Ciocalteu reagent, potassium ferricyanide, ferric chloride, gallic acid, quercetin and ursolic acid were obtained from Sigma-Aldrich.

\section{Preparation of extract}

The dried root of Siberian ginseng (20 gms) were soaked in methanol for $24 \mathrm{~h}$. Extract was filtered and evaporated using a rotary vacuum evaporator at $40{ }^{\circ} \mathrm{C}$. Obtained residues was suspended in methanol for further analysis.

\section{Primary phytochemical anaysis}

The phytochemical Screening of Alkaloids, Flavonoid, phenolics, terpenoids, flavonoids, tannins, carbohydrates, glycosides and saponins in methanol root extract of Siberian ginseng were determined using previously described method of A. Sofowora [11].

\section{Total phenolic content (TPC)}

The total phenolic content of siberian ginseng root extract was determined using of Singleton and Rossi method [12]. Total Phenol Content was expressed as gallic acid equivalents (GAE/g dry sample). Each tests was done in triplicate.

\section{Total flavonoid content (TFC)}

The Total Flavonoids Content of root extract of siberian ginseng was investigated using the colorimetric method [12]. Total Flavonoids Content was expressed as mg of quercetin equivalent $(\mathrm{QEs} / \mathrm{g} / \mathrm{dry}$ sample). All tests were done triplicate.

\section{DPPH radical scavenging activity}

The free radical scavenging activity of root extract of siberian ginseng was determined DPPH assay [13]. $0.8 \mathrm{ml}$ of DPPH solution was plated in 96-well plates, and $0.2 \mathrm{ml}$ of the sample was or a control added to each well. The reaction mixture was incubated for 
30 min in dark condition at room temperature. Then absorbance was recorded at $520 \mathrm{~nm}$.

The $\mathrm{RC}_{50}$ (50\% reduction of DPPH radicals) was observed from a graph. Butylatedhydroxytoluene was used as the standard.

\section{FRAP assay}

The total reducing power of siberian ginseng root extract was evaluated by described [14]. Sample was mixed with $0.5 \mathrm{ml}$ of phosphate buffer $(0.2 \mathrm{M}, \mathrm{pH} 6.6)$ and $0.5 \mathrm{ml}$ of potassium ferricyanide $(1 \%, \mathrm{w} / \mathrm{v})$. Then incubation at $50{ }^{\circ} \mathrm{C}$ for $20 \mathrm{~min}$. The reaction was stopped by addition of $10 \%$ of $0.5 \mathrm{ml}$ trichloroacetic acid solution and centrifuged the mixture at 2,500 rpm for $10 \mathrm{~min}$. $0.5 \mathrm{ml}$ supernatant was mixed with $0.5 \mathrm{ml}$ distilled water and $0.1 \mathrm{ml}$ of ferric chloride solution $(0.1 \%, \mathrm{w} / \mathrm{v})$. The absorbance was recorded at $750 \mathrm{~nm}$.

\section{RESULTS}

\section{Phytochemical analysis}

The primary phytochemical analysis of Siberian ginseng root was shown in table 1 . Root methanol extract was determined Phenol, Flavonoid, Tannins, Saponins and Glycoside.

Table 1: Phytochemical analysis of siberian ginseng root

\begin{tabular}{ll}
\hline Phytochemical name & Methanol extract \\
\hline Alkaloids & -ve \\
Carbohydrates & -ve \\
Glycosides & $+\mathrm{ve}$ \\
Saponins & $+\mathrm{ve}$ \\
Flavonoids & $+\mathrm{ve}$ \\
Phenol & $+\mathrm{ve}$ \\
Tannins & $+\mathrm{ve}$ \\
\hline
\end{tabular}

Table 2: Total phenol and flavonoid content of root methanol extract of siberian ginseng

\begin{tabular}{lll}
\hline & Total phenol content (mg GAE/g DW) & Total flavonoid content (mg QE/g DW) \\
\hline Root Methanol Extract & $12.6 \pm 1.13$ & $9.8 \pm 0.20$ \\
\hline
\end{tabular}

Table 3: DPPh and FRAP assay for root of siberian ginseng

\begin{tabular}{lll}
\hline & DPPH $\left(\mathrm{RC}_{\mathbf{5 0}} \boldsymbol{\mu \mathrm { g }} / \mathbf{m l}\right)$ & FRAP (mmol/g) \\
\hline Root Methanol Extract & $713.42 \pm 11.55$ & $0.13 \pm 0.01$ \\
\hline
\end{tabular}

\section{Total phenolic and total flavonoids content}

The Total Phenol and Flavonoids content of root methanolic extracts of siberian ginseng were presented in table 1 . Total Phenol content was determined $12.6 \pm 1.13 \mathrm{mg} \mathrm{GAE} / \mathrm{g}$ or total flavonoids content was determined $9.8 \pm 0.20 \mathrm{mg} Q \mathrm{QEs} / \mathrm{g}$ dry sample.

\section{DPPH and FRAP analysis}

The examination of antioxidant properties of siberian ginseng root is measured an important work in developing new antioxidant agents with low toxicity and less side effects. Therefore, we investigated the antioxidant properties of Siberian ginseng root $\mathrm{MeOH}$ extract was analyzed for antioxidant activities based on DPPH free radical scavenging activity and FRAP. Table 2 were presented DPPH free radical scavenging activity and reducing the power of methanol root extract of siberian ginseng.

\section{CONCLUSION}

We analyzed the Total Phenol and Flavonoids content and antioxidant properties suggested that Siberian ginseng root is an abundant source of natural antioxidant activities. In addition, the presence of ursolic acid and sesquiterpene hydrocarbons in the root extract of Siberian ginseng shown the potential source as a crude drug and dietary health supplement. Further studies on the isolation and characterization of the root extract and toxicity should be tested to confirm the safety use.

\section{FUNDING}

Nil

\section{AUTHORS CONTRIBUTIONS}

All the authors have contributed equally.

\section{CONFLICTS OF INTERESTS}

Declared none

\section{REFERENCES}

1. Hwang HS, Lee H, Choi YE. Transcriptomic analysis of Siberian ginseng (Eleutherococcussenticosus) to discover genes involved in saponin biosynthesis. BMC Genomics 2015;16:180.

2. Huang L, Zhao H, Huang B, Zheng C, Peng W, Qin L. Acanthopanaxsenticosus: review of botany, chemistry and pharmacology. Pharmazie 2011;66:83-97.

3. Lee S, Shin KH. The chemistry of secondary products from Acanthopanax species and their pharmacological activities. Nat Prod Sci 2002;8:111-26.

4. Sun YL, Liu LD, Hong SK. Eleutherococcus senticosus as a crude medicine: a review of biological and pharmacological effects. J Med Plants Res 2011;5:5946-52.

5. Ahn J, Um MY, Lee H. Eleutheroside E, an active component of Eleutherococcussenticosus, ameliorates insulin resistance in type 2 diabetic db/db mice. Evid Based Complement Alternat Med 2013. Doi:10.1155/2013/934183

6. Lee D, Park J, Yoon J. Neuroprotective effects of Eleutherococcussenticosus bark on transient global cerebral ischemia in rats. J Ethnopharmacol 2012;139:6-11.

7. Hibasami H, Fujikawa T, Takeda H. Induction of apoptosis by Acanthopanaxsenticosus HARMS and its component, sesamin in human stomach cancer KATO III cells. Oncol Rep 2000;7:1213-6.

8. Soo KH, Young PS, Kyoung KE. Acanthopanaxsenticosus has a heme oxygenase-1 signaling-dependent effect on porphyromonasgingivalis lipopolysaccharide-stimulated macrophages. J Ethnopharmacol 2012;142:819-28.

9. Huang L, Zhao H, Huang B, Zheng C, Peng W, Qin L. Acanthopanaxsenticosus: review of botany, chemistry and pharmacology. Pharmazie 2011;66:83-97.

10. Ha ES, Hwang SH, Shin KS. Anti-metastatic activity of glycoprotein fractionated from Acanthopanaxsenticosus, the involvement of NK-cell and macrophage activation. Arch Pharm Res 2004;27:217-24. 
11. Sofowora. Recent trends in research into african medicinal plants. J Ethnopharmacol 1993;38:209.

12. VL Singleton, JA Rossi. Colorimetry of total phenolics with phosphomolybdic phosphotungstic acid reagents. Am J Enol Viticulture 1965;16:144-58.
13. Hyun TK, Kim MO, Lee H, Kim Y, Kim E, Kim JS. Evaluation of anti-oxidant and anti-cancer properties of Dendropanax morbifera leveille. Food Chem 2013;141:1947-55.

14. Lee YJ, Kim DB, Lee JS, Cho JH, Kim BK, Choi HS, et al. Antioxidant activity and anti-adipogenic effects of wild herbs mainly cultivated in Korea. Molecules 2013;18:12937-50. 